\title{
Efficacy of Kalo Jeera seeds (Nigella sativa) and Thankuni (Centella asiatica) supplementation on the growth performance of broiler chicken
}

\author{
Chandan Kumar Sarkar ${ }^{1}$, Mahbub Mostofa ${ }^{1}$, Md. Mahmudul Hasan Sikder ${ }^{1}$, \\ Wahedul Karim Ansari², Md. Mostakin Ahamed ${ }^{2}$, Md. Shafiullah Parvej², \\ Muhammad Rakibul Hasan ${ }^{3 *}$
}

\begin{abstract}
${ }^{1}$ Department of Pharmacology, Bangladesh Agricultural University, Mymensingh-2202, Bangladesh ${ }^{2}$ Department of Microbiology, Bangladesh Agricultural University, Mymensingh-2202, Bangladesh

${ }^{3}$ Department of Physiology, Bangladesh Agricultural University, Mymensingh-2202, Bangladesh
\end{abstract}

Received: 24 August 2015

Accepted: 26 August 2015

\section{*Correspondence:}

Muhammad Rakibul Hasan

E-mail: rakibul_vet@yahoo.com

Copyright: () the author(s), publisher and licensee Medip Academy. This is an open-access article distributed under the terms of the Creative Commons Attribution Non-Commercial License, which permits unrestricted non-commercial use, distribution, and reproduction in any medium, provided the original work is properly cited.

\begin{abstract}
Background: In modern era, treatment methods become diversified and developed day by day and organic medicine is one of the modern technology which also introduced in our poultry sector. This experiment was conducted to evaluate the efficacy of Thankuni (Centella asiatica) and Kalo Jeera (Nigella sativa) powdered supplementation as a growth promoter in broiler chickens.

Methods: A total of 20 day-old Cobb 500 broiler chicks were randomly divided into two groups, A and B after seven days of acclimatization. The group A was kept as control and fed on only normal balanced diet. The group B was treatment group fed on normal diet with additional supplementation of Thankuni and Kalo Jeera powder in water. For observation of growth rate, live body weight was taken at first day and every seven days interval up to $5^{\text {th }}$ weeks. Besides it hematological tests were performed at $35^{\text {th }}$ days for searching hematological changes in both groups.

Results: The initial body weight of groups A and B on $1^{\text {st }}$ day of this experiment were $43.00 \pm 0.56 \mathrm{gm}$ and $42.50 \pm$ $0.35 \mathrm{gm}$, respectively and after $35^{\text {th }}$ day of experiment final body weight were $1450 \pm 57.35 \mathrm{gm}$ and $1700 \pm 58.56 \mathrm{gm}$ $(\mathrm{p}<1 \%)$ respectively. The growth rate of treatment group B was $17.24 \%$ more $(\mathrm{p}<1 \%)$ than that of control birds. Although the dressing percentage of both group was equal but relative weight of heart, liver, spleen and pancreas were significantly higher $(\mathrm{p}<0.1)$ in treatment group indicates better flock health. Feed Conversion Ratio (FCR) were 1.88 in treated birds and 2.28 in control birds was the sign of economy rate of production and were analyzed and found that net profit per broiler was Tk. 10.50 (0.12 USD) and Tk. 33.00 (0.4 USD), respectively. General blood parameters of treatment group were non-significantly higher than control group.

Conclusions: The results suggest that better growth performance were achieved in broilers supplemented with Thankuni leaf and Kalo Jeera. Both of these two herbal medicines have antimicrobial, immunostimulatory, anti-stress, fungi static, insecticidal and liver tonic properties so that there were no mortality rate. Now it can be said that uses of Thankuni and Kalo Jeera has beneficiary effects in broiler production.
\end{abstract}

Keywords: Thankuni, Kalo Jeera, Broiler, Body weight, Profit

\section{INTRODUCTION}

Many countries have strict law against using of antibiotics and feed additives as growth promoter in poultry diets due to its residual effect on human body and bacteria develop resistance to those drugs thus producing many new diseases. ${ }^{1}$ Researchers are now trying to give emphasis on natural plant extract in exchange of 
antibiotics for the control of diseases and better performance of growing birds. ${ }^{2,3}$ Among various medicinal plants, Nigella sativa ( $N$. sativa) (Family Ranunculaceae) is emerging as a miracle herb. $N$. sativa is commonly known as black seed. $N$. sativa is native to Southern Europe, North Africa and Southwest Asia and it is cultivated in many countries in the world like Middle Eastern Mediterranean region, South Europe, India, Pakistan, Syria, Turkey, Saudi Arabia. ${ }^{4,5}$ N. sativa has been extensively studied for its biological activities and therapeutic potential and shown to possess wide spectrum of activities viz. as diuretic, antihypertensive, antidiabetic, anticancer and immunomodulatory, analgesic, antimicrobial, anthelmintic, analgesics and antiinflammatory, spasmolytic, bronchodilator, gastro protective, hepato protective, renal protective and antioxidant properties. ${ }^{6}$ Most of the therapeutic properties of this plant are due to the presence of thymoquinone, thymol and carvacol. ${ }^{4,7,8}$ Triterpenoid and saponins, the primary constituents of Centella asiatica are mainly believed to be responsible for wide therapeutic activities. Apart from wound healing, the herb is recommended for the treatment of various skin conditions such as leprosy, lupus, varicose ulcers, eczema, psoriasis, diarrhoea, fever, amenorrhea, diseases of the female genitourinary tract and also for relieving anxiety and improving cognition. ${ }^{9,10}$ Bangladesh is a densely populated country where demand of protein of this booming population is a great threat. Each person should take $56 \mathrm{~kg}$ of meat and 365 eggs every year. But in Bangladesh, per head intake of meat is only $11.27 \mathrm{~kg}$ and 30 eggs per year. ${ }^{11}$ Broiler production has grown dramatically in the past two decades; for achieving the maximum expression of their genetic potential poultry farmers make use of synthetic growth promoters. ${ }^{12}$ Many of these growth promoters are supplemented to broiler diets to gain rapid growth, but their use have shown many disadvantages like high cost, adverse side effect on health of birds and long residual properties and carcinogenic effect in humans. ${ }^{13}$ So, researchers are now concentrating efforts on the use of beneficial herbs and plants, which can be safely used to increase production and also contains pharmacologicallyactive substances and are known to produce certain chemicals that are naturally toxic to bacteria. ${ }^{14}$ In view of these, this work has been undertaken to investigate the growth performance of broilers through supplementation of Thankuni and Kalo Jeera and examine the effect of Thankuni and Kalo Jeera on blood parameters (TEC, ESR and $\mathrm{Hb}$ ) of broilers.

\section{METHODS}

This study was executed at the Department of Pharmacology, Bangladesh Agricultural University (BAU), Mymensingh; during the period from $26^{\text {th }}$ July, 2014 to $5^{\text {th }}$ October, 2014. The experimental units were kept on a floor litter system in separate pens each measuring $3 \times 4$ square feet. A total of 20 day-old Cobb 500 broiler chicks purchased from a local hatchery (Nourish Poultry \& Hatchery Ltd.) were randomly divided into 2 groups (A and B) after seven days of acclimation. All the birds were provided same management conditions like floor space, temperature, relative humidity, ventilation and light. Young, fresh \& green Thankuni leaves were harvested, washed, chopped and air dried in a well-ventilated room for 10 days. The dried leaves were ground using the Mixture blender to produce Thankuni powder. Kalo Jeera seeds were purchased from local market, BAU, and Mymensingh, washed and dried and crushed in mortar pestle to paste. Treatment group B fed on balanced diet with mixture of Thankuni and Kalo Jeera (1\% each in drinking water). All the chicks were closely observed for 35 days. Mean live weight gains of each group were recorded on $1^{\text {st }}, 7^{\text {th }}$, $14^{\text {th }}, 21^{\text {st }}, 28^{\text {th }}$ and $35^{\text {th }}$ days. Blood samples were collected from wing vein of chicken of both control and treated groups at $35^{\text {th }}$ day. Total Erythrocyte Count (TEC), hemoglobin concentrations ( $\mathrm{Hb})$, Erythrocyte Sedimentation Rate (ESR) was done following the method described by Lamberg and Rothstein. ${ }^{11}$ After postmortem of birds, liver, spleen, heart, pancreas, and gizzard of 5 birds from each group was collected and then measured by air tight electric balance. The dressing percentage was also evaluated by comparing between live and carcass body weight. During the 35 days of experimental period, growth performance was evaluated and mortality was recorded throughout the study.

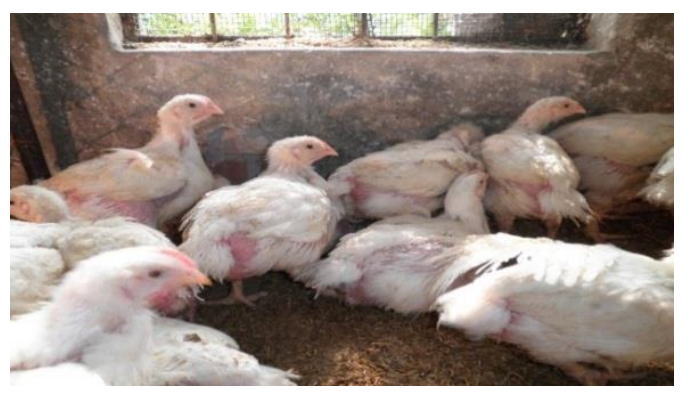

Figure 1: Treatment group of broiler.

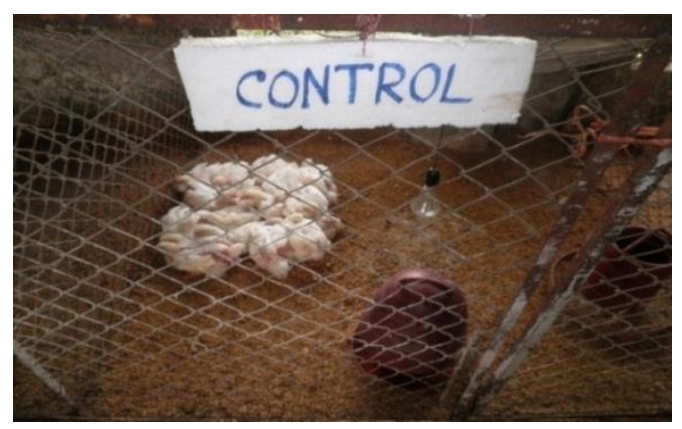

Figure 2: Control group of broiler.

\section{RESULTS}

\section{Body weight of broilers and FCR}

The experiment was conducted according to the completely randomized design and data about per 
replicate body wt., weekly body wt., weekly feed consumptions and mortality were recorded throughout the experimental period (1-5 weeks of age). The birds were supplied Thankuni and Kalo Jeera by using drinking water in B Group and gained the higher live weight which is shown in Table 1. In control group (Group A) initial average live weight on $1^{\text {st }}$ day was $42.10 \pm 0.56 \mathrm{gm}$, final live weight $1442 \pm 37.35 \mathrm{gm}$, weight gain $1400 \pm 43.79$ gm and Feed Conversion Ratio (FCR) was 2.28 (Table 2 ). In Group $B$ initial average live weight on $1^{\text {st }}$ day was $41.50 \pm 0.35 \mathrm{gm}$, final live weight $1700 \pm 58.56 \mathrm{gm}$, weight gain $1657.50 \pm 54.25$ gm and FCR 1.88 (Table 2).

Table 1: Body weight of broilers and FCR.

\begin{tabular}{|lllllll|}
\hline Body wt. $(\mathrm{g})$ & $\begin{array}{l}\text { Day 1 } \\
\text { Mean } \pm \text { SD }\end{array}$ & $\begin{array}{l}\text { Day 7 } \\
\text { Mean } \pm \text { SD }\end{array}$ & $\begin{array}{l}\text { Day 14 } \\
\text { Mean } \pm \text { SD }\end{array}$ & $\begin{array}{l}\text { Day 21 } \\
\text { Mean } \pm \text { SD }\end{array}$ & $\begin{array}{l}\text { Day 28 } \\
\text { Mean } \pm \text { SD }\end{array}$ & $\begin{array}{l}\text { Day 35 } \\
\text { Mean } \pm \text { SD }\end{array}$ \\
\hline Control $(\mathrm{n}=10)$ & $42.20 \pm 2.80$ & $158.54 \pm 4.80$ & $550.89 \pm 8.90$ & $935.70 \pm 10.90$ & $1375 \pm 18.00$ & $1442 \pm 32.00$ \\
\hline Treatmet $(\mathrm{n}=10)$ & $41.50 \pm 3.84$ & $173.90 \pm 5.67$ & $607.79 \pm 21.08$ & $1045 \pm 16.90$ & $1560 \pm 43.09$ & $1700.98 \pm 45.89$ \\
\hline \% increase & 0 & 10.10 & 10.23 & 11.22 & 13.45 & 17.89 \\
\hline
\end{tabular}

$\%$ body weight gain $=(\mathrm{T}-\mathrm{C}) \mathrm{X} 100 / \mathrm{C}$, Where, $\mathrm{C}$ means Control \& T means Treatment

Table 2: Statistical analysis: Body weight of broilers and FCR.

\begin{tabular}{|c|c|c|c|c|}
\hline Variables & Treatments & $\begin{array}{l}\text { Average weight } \\
(\text { Mean } \pm \text { SEM) }\end{array}$ & p value & $\begin{array}{l}\text { Significance } \\
\text { level }\end{array}$ \\
\hline \multirow{2}{*}{ Initial live weight ( $\mathrm{g}$ ) on $1^{\text {th }}$ day } & Control & $42.20 \pm 2.56$ & \multirow{2}{*}{0.000} & \multirow{2}{*}{$* *$} \\
\hline & Thankuni and Kalo Jeera & $41.50 \pm 3.35$ & & \\
\hline \multirow{2}{*}{ Final live weight ( $g$ ) on $35^{\text {th }}$ day } & Control & $1442 \pm 45.35$ & \multirow{2}{*}{0.000} & \multirow{2}{*}{$* *$} \\
\hline & Thankuni and Kalo Jeera & $1700.00 \pm 48.56$ & & \\
\hline \multirow{2}{*}{ Weight gain (g) } & Control & $1400 \pm 43.79$ & \multirow{2}{*}{0.000} & \multirow{2}{*}{$* *$} \\
\hline & Thankuni and Kalo Jeera & $1657.5 \pm 54.25$ & & \\
\hline \multirow{2}{*}{ Feed consumption (g) } & Control & $3200 \pm 35.49$ & \multirow{2}{*}{0.000} & \multirow{2}{*}{$* *$} \\
\hline & Thankuni and Kalo Jeera & $3200 \pm 52.29$ & & \\
\hline \multirow{2}{*}{ FCR } & Control & 2.28 & & \\
\hline & Thankuni and Kalo Jeera & 1.88 & & \\
\hline
\end{tabular}

\section{Dressing percentages, relative giblet weight (heart, gizzard, liver and spleen) and pancreas weight of broilers supplemented with or without Thankuni and Kalo Jeera from 1-5 weeks of age}

Dressing percentage is slightly increased in treated groups than in control. Relatively each organ weight had increased in treated ones except gizzard weight which is slightly decreased in Thankuni and Kalo Jeera treated groups than the control (Table 3). Statistical analysis of the data shows non-significant between the dressing percentages of the birds of two groups (Table 3). Statistical analysis of the data did not show any difference between the relative gizzard weights of the birds of two groups (Table 2). Statistical analysis of the data shows $1 \%$ level of significance of relative heart, liver, spleen and pancreas weight between the birds of two groups using drinking water with or without supplementation of Thankuni and Kalo Jeera (Table 2).

\section{Economies of production}

The average rearing cost of broilers in two groups were Tk. 178.00 and Tk. 188.00 for A and B Groups respectively excluding the cost of labour. Miscellaneous cost summed up Tk. 20 per broiler, which included the estimated cost of electricity, litter and disinfectant. The average live weight/broiler in Groups A and B were 1.442 $\mathrm{kg}$ and $1.700 \mathrm{~kg}$ respectively. The broilers were sold in live weight basis at the rate of Tk. $130 / \mathrm{kg}$. The net profit/kg live weight in the respective group excluding the cost of labour was found to be Tk. 6.60 and Tk. 19.41 respectively (Table 4).

\section{Effects of Thankuni and Kalo Jeera on hematological parameters of broiler}

Observation of hematological parameter (RBC, $\mathrm{Hb}$ and ESR) on $35^{\text {th }}$ day did not show any significant difference $(\mathrm{p}<0.05)$ between the control and Thankuni and Kalo Jeera treated groups (Table 5). Total Erythrocyte Count (TEC) in control group was $2.01 \pm 0.102 \mathrm{million} / \mu \mathrm{l}$ and $2.11 \pm 0.23$ million $/ \mu 1$ in Group B. ESR was little bit higher in Group B (4.83 $\pm 0.64 \mathrm{~mm}$ in first our) than control bird. Hemoglobin level was $7.10 \pm 0.13 \mathrm{gm} / \mathrm{dl}$ $7.35 \pm 0.13 \mathrm{gm} / \mathrm{dl}$ in control and treatment group respectively. 
Table 3: Dressing percentages, relative giblet weight (heart, gizzard, liver and spleen) and pancreas weight of broilers supplemented with or without Thankuni and Kalo Jeera from 1-5 weeks of age.

\begin{tabular}{|c|c|c|c|c|}
\hline Variables & Treatments & $\begin{array}{l}\text { Average value } \\
(\text { Mean } \pm \text { SEM })\end{array}$ & $\mathrm{p}$ value & $\begin{array}{l}\text { Significance } \\
\text { level }\end{array}$ \\
\hline \multirow{2}{*}{ Dressing percentage } & Control & $64.410 \pm 0.414$ & \multirow{2}{*}{0.939} & \multirow{2}{*}{ NS } \\
\hline & Thankuni and Kalo Jeera & $64.470 \pm 0.961$ & & \\
\hline \multirow{2}{*}{ Relative heart weight } & Control & $0.420 \pm 0.032$ & \multirow{2}{*}{0.002} & \multirow{2}{*}{$* *$} \\
\hline & Thankuni and Kalo Jeera & $0.501 \pm 0.032$ & & \\
\hline \multirow{2}{*}{ Relative gizzard weight } & Control & $1.460 \pm 0.034$ & \multirow{2}{*}{0.606} & \multirow{2}{*}{ NS } \\
\hline & Thankuni and Kalo Jeera & $1.440 \pm 0.014$ & & \\
\hline \multirow{2}{*}{ Relative liver weight } & Control & $2.530 \pm 0.034$ & \multirow{2}{*}{0.001} & \multirow{2}{*}{$* *$} \\
\hline & Thankuni and Kalo Jeera & $2.610 \pm 0.032$ & & \\
\hline \multirow{2}{*}{ Relative spleen weight } & Control & $0.120 \pm 0.011$ & \multirow{2}{*}{0.011} & \multirow{2}{*}{$* *$} \\
\hline & Thankuni and Kalo Jeera & $0.130 \pm 0.015$ & & \\
\hline \multirow{2}{*}{ Relative pancreas weight } & Control & $0.230 \pm 0.011$ & \multirow{2}{*}{0.001} & \multirow{2}{*}{$* *$} \\
\hline & Thankuni and Kalo Jeera & $0.250 \pm 0.017$ & & \\
\hline
\end{tabular}

** = Significant at $1 \%$ level of probability $(0.00-0.01), \mathrm{NS}=$ Not significant $(\geq 0.05)$, Relative weight $(\mathrm{g})=$ Weight of organ/Live body weight of bird $x 100$, Dressing \% = Dress weight of bird/Live weight of bird

Table 4: Economies of production.

\begin{tabular}{|lll|}
\hline Description & Group-A & Group-B \\
\hline Cost/chick (Taka) & 30.00 & 30.00 \\
\hline Average feed consumed (kg)/chicks & 3.200 & 3.200 \\
\hline Feed price/kg (Taka) & 40.00 & 40.00 \\
\hline $\begin{array}{l}\text { Cost of herbal growth promoters } \\
\text { (Taka) }\end{array}$ & 0.00 & 10.00 \\
\hline Feed cost (Taka) & 128.00 & 128.00 \\
\hline Miscellaneous (Taka) & 20.00 & 20.00 \\
\hline Total cost/broiler (Taka) & 178.00 & 188.00 \\
\hline Average live weight (kg) & 1.442 & 1.700 \\
\hline Sale price/kg live wt. (Taka) & 130.00 & 130.00 \\
\hline Sale price/broiler (Taka) & 187.50 & 221.00 \\
\hline Net profit/broiler (Taka) & 9.50 & 33.00 \\
\hline
\end{tabular}

Table 5: Effects of Thankuni and Kalo Jeera on hematological parameters of broiler.

\begin{tabular}{|llll|}
\hline Group & $\begin{array}{l}\text { TEC } \\
\text { (million/ul) }\end{array}$ & $\begin{array}{l}\text { ESR }(\mathrm{mm} \text { in } \\
\text { first hour) }\end{array}$ & $\mathrm{Hb}(\mathrm{gm} / \mathrm{dl})$ \\
\hline Control & $2.01 \pm 0.102$ & $4.60 \pm 0.58$ & $7.10 \pm 0.13$ \\
\hline Treatment & $2.11 \pm 0.23$ & $4.83 \pm 0.64$ & $7.35 \pm 0.13$ \\
\hline p value & - & - & - \\
\hline Level of sig. & NS & NS & NS \\
\hline
\end{tabular}

\section{DISCUSSION}

Addition of herbal growth promoter Thankuni and Kalo Jeera improved the weight gain of the broilers. The values for liver, heart, gizzard and lungs did not differ significantly, this could be linked to the absence of antinutritional factors in the diets. The birds had been drunken water supplemented with herbal growth promoters Thankuni and Kalo Jeera utilized their feed more efficiently than those supplied drinking water without addition of the growth promoters. ${ }^{15}$ The use of Thankuni and Kalo Jeera with drinking water showed more increase in live weight of the birds as compared to control group in this study. ${ }^{15}$ While supplementation of Thankuni and Kalo Jeera did not exhibit any effect on the dressing percentage values of the broilers but use of various levels of herbal growth promoters in the rations exhibited an increase in the profit margin of the broilers as compared to those using ration without the addition of these growth promoters. Supplementation of $1 \%$ Thankuni and Kalo Jeera with drinking water was found to be more profitable than without garlic supplementation in broiler rearing. ${ }^{16}$ General blood parameters of both treated and control birds were near about equal which indicates that there were no extraordinary side effects of these two extracts on normal physiology. But in case of treated broiler, birds show somewhat improvement of blood parameters which may be responsible for more nutrients transportation. ${ }^{17}$

\section{CONCLUSION}

This study has revealed that there is a positive relationship between supplementation of Thankuni and Kalo Jeera and on the body weight gain significantly (at $1 \%$ level) increases. The hematological parameter TEC, ESR and PCV value of treatment group showed nonsignificant difference between the treatment and control groups of broilers. No mortality was observed in broiler during experimentation because of antimicrobial, immunostimulatory, anti-stress, fungi static, insecticidal and liver tonic properties and activities of those two herbal medicines. Thereby, these are helpful in treating many serious systemic diseases, as well as localized infections. Now it is the need of the hour to work more extensively on the medicinal plants in the greater interest 
of mankind to protect human being from irrational use of antibiotics and antimicrobial growth promoters.

Funding: No funding sources

Conflict of interest: None declared

Ethical approval: The study was approved by the institutional animal ethics committee

\section{REFERENCES}

1. Baserisalehi M, Bahador N, Kapadnis BP. A comparison study on animicrobial susceptibility of Campylobacter spp. Isolates from faecal samples of domestc animals and poultry in India and Iran. J Boil Sci. 2007;7:977-80.

2. Jamroz D, Kamel C. Plant extracts enhance broiler performance in non-ruminant nutrition: Antimicrobial agents and plant extracts on immunity, health and performance. J Anim Sci. 2002;80:41.

3. Nobakht A, Mansoub NH, Nezhady MAM. Effect of Melissa officinalis L., Tanacetum balsamita L. and Ziziphora clinopodioides $L$. on performance, blood biochemical and immunity parameters of laying hens. Asian J Anim Vet Adv. 2012;7:74-9.

4. Harzallah HJ, Kouidhi B, Flamini G, Bakhrouf A, Mahjoub T. Chemical composition, antimicrobial potential against cariogenic bacteria and cytotoxic activity of Tunisian Nigella sativa essential oil and thymoquinone. Food Chem. 2011;129:1469-74.

5. Kanter MI, Meral Sdede, Cemek M, Ozbek H, Uygan L, Gunduz H. Effects of N. sativa L. and Urtica dioica $L$. on lipid peroxidation, antioxidant enzyme systems and some liver enzymes in Cc 14treated rats. Pathol Clin Med. 2003;50:264-8.

6. Abdel-Zaher AO, Abdel-Rahman MS, Elwasei FM. Protective effect of Nigella sativa oil against tramadol-induced tolerance and dependence in mice: role of nitric oxide and oxidative stress. Neurotoxicology. 2011;32:725-33.

7. Nasir ZAR, Hayat AZ, Shakoor HI. Effect of Kalongi (Nigella sativa) seeds on egg production and quality in egg production layers. J Anim Plant Sci. 2005;15:22-4.

8. Toghyani MA, Ghalamkari GG, Mohammadrezaei M. Growth performance, serum biochemistry and blood hematology of broiler chicks feed different levels of black seed (Nigella sativa) and peppermint (Mentha piperita). Livest Sci. 2010;129:173-8.

9. Kashmira JG, Patel JA, Gajjar AK. Pharmacological review on Centella asiatica: a potential herbal cureall. Ind J Pharm Sci. 2010;72:546-56.

10. Wiesława B, Znajdek-Awiżeń P, Studzińska-Sroka E, Brzezińska M. Centella asiatica in cosmetology. Pos Derma Aler. 2013;30:46-9.

11. Das SC, Chowdhury SD, Khatun MA, Nishibori M, Isobe N, Yoshimura Y. Small-scale family poultry production, poultry production profile and expected future projection in Bangladesh. World's Poul Sci. 2008;64:99-118.

12. Sadeghi GH, Tabiedian SA. Effect of different energy to protein ratio and tallow supplementation on broiler performance. Int J Poul Sci. 2005;4:97681.

13. Butaye P, Devriese LA, Haesebrouck F. Antimicrobial growth promoters used in animal feed: effects of less well known antibiotics on Gram-positive bacteria. Clin Microbiol Rev. 2003;6:175-88.

14. Basile A, Giordano S, Lopez-saez JA, Cobianchi RC. Antibacterial activity of pure flavonoids isolated from mosses. Photochemistry. 1999;52:1479-82.

15. Ahmad T, Ansari JZ, Ahsanui H, Yousaf M, Sarzamin K. Evaluation of different medicinal plants as growth promoters for broiler chicks. Sarhad J Agric. 2008;24:180-5.

16. Sarker EH, Khokon LU, Rahman MA, Mostofa M, Rahman M. Comparative efficacy of probiotic Thankuni leaves and vitamin AD3E as a growth promoter on broilers. Int J Nat Soc Sci. 2014;1:2632.

17. Jamroz D, Kamel C. Plant extracts enhance broiler performance in non-ruminant nutrition: antimicrobial agents and plant extracts on immunity, health and performance. J Anim Sci. 2002;80:41.

Cite this article as: Sarkar CK, Mostofa M, Sikder MMH, Ansari WK, Ahamed MM, Parvej MS, Hasan MR. Efficacy of Kalo Jeera seeds (Nigella sativa) and Thankuni (Centella asiatica) supplementation on the growth performance of broiler chicken. Int J Sci Rep 2015;1(4):196-200. 